\title{
Effects of Malnutrition and Chronic Reserpine Treatment on Pancreatic Exocrine Function ${ }^{1}$
}

\author{
DEE HAZLETT, MURRAY KORC, AND PATSY M. BRANNON \\ Departments of Nutrition and Food Science [D.H., P.M.B.] and Internal Medicine [M.K.], University of Arizona, \\ Tucson, Arizona 85721
}

\begin{abstract}
The chronically reserpine-treated rat, an experimental model for cystic fibrosis, exhibits generalized exocrinopathy, impaired pancreatic secretion, and decreased pancreatic amylase. Although chronic reserpine treatment induces malnutrition by decreasing food consumption and growth, the effects of this malnutrition per se on the exocrine pancreas have not been considered. In this study, the effects of chronic reserpine treatment and malnutrition on the exocrine pancreas were determined using pair-fed controls. Male, Sprague-Dawley rats were treated daily subcutaneously for 5 to 7 days with: 1) no injection (control), 2) $1.0 \mathrm{ml} / \mathrm{kg}$ vehicle or sham (controlsham, pair fed-sham), or 3) $0.5 \mathrm{mg} / \mathrm{kg}$ reserpine (chronically reserpine-treated). Both chronic reserpine-treatment and pair-feeding significantly decreased food consumption $(40 \%)$, body weight (51 and $59 \%$ ), total pancreatic amylase $(49$ and $56 \%)$ and specific amylase activity (62 and $61 \%)$, pancreatic protein (65 and $75 \%$ ), and pancreatic weights (62 and $65 \%$ ) compared to controls. These decreases, however, were comparable between the chronically reserpine-treated and pair fed-sham rats. In contrast, the secretory response to the biologically active cholecystokinin analog cholecystokinin octapeptide was significantly attenuated in isolated pancreatic acini prepared from reserpinetreated rats compared to that from either control or pairfed sham rats. Malnutrition decreased pancreatic amylase activity and protein comparably to reserpine treatment, but only partially attenuated the secretory response to cholecystokinin octapeptide. Based on the results of this study, pair-fed controls should be used to distinguish between the effects of reserpine alone and the induced malnutrition on pancreatic exocrine function in studies of this experimental model of cystic fibrosis. (Pediatr Res 20: 1236-1239, 1986)
\end{abstract}

\section{Abbreviations}

$\mathrm{CCK}_{8}$, cholecystokinin octapeptide

$\mathrm{CF}$, cystic fibrosis

$\mathrm{C}$, control

CS, control sham

PFS, pair-fed sham

CRT, chronic reserpine treated

KHB, Krebs Hanseleit bicarbonate buffer

HR, HEPES-buffered Ringer's solution

Received February 27, 1986: accepted July 9, 1986.

Correspondence Patsy M. Brannon, Ph.D., 309 Shantz Bldg. University of Arizona, Tucson, AZ 85721

Supported in part by Cystic Fibrosis Foundation New Investigator Award to PB and McDonald Foundation award to MK. Submitted in partial fulfillment of M.S. requirements, Graduate Group in Nutritional Science. University of Arizona.

'Presented in part at 1985 FASEB meeting (Anaheim. CA) [Hazlett DA, Brannon PM 1985 Interaction of malnutrition and pancreatic exocrine function in reserpine-treated rats. Fed Proc 44:940]
ANOVA, analysis of variance

LSD, least significant difference

$\mathrm{CF}$ is the most prevalent lethal genetic disease in the Caucasian race occurring in 1:2000 live births. $\mathrm{CF}$ is an autosomal recessive disorder, but the exact nature and mechanism of the defect remains unknown. $\mathrm{CF}$ is characterized by chronic pulmonary disease and exocrine malfunction of the pancreas, sweat glands, salivary glands, and the mucus-producing glands of the gastrointestinal tract and respiratory system. It has been difficult to study the pancreatic defects in this disease because of the lack of available human tissue and the lack of an animal model. However, in 1975, Martinez and colleagues $(1,2)$ proposed the chronically reserpine-treated rat as an experimental animal model for CF. Reserpine-treated rats exhibit altered glycoprotein synthesis and secretion in the cells and ductus of salivary $(1,4)$, tracheobronchial $(5,6)$, pancreatic exocrine glands $(7)$, and the intestine $(8,9)$. In addition they manifest CF-like abnormalities in salivary gland secretions including alterations in volume, electrolyte, and total protein concentrations $(2,3,10,11)$, and they show morphological abnormalities in the pancreas $(12,14)$, impaired pancreatic acinar secretion $(13,15)$, and decreased pancreatic acinar amylase content (16). These characteristics are similar to those in patients with $\mathrm{CF}$.

The exact mechanisms by which chronic reserpine treatment exerts these effects are not known. Reserpine's depletion of catecholamine at nerve endings does not appear the cause of these effects (2). Reserpine may act directly on the exocrine cell membrane or may exert a toxic effect on cellular metabolism which leads to alterations in enzyme synthesis, storage, or secretion $(4,17)$. Reserpine treatment of colonic cells in vitro increases mucus production similarly to that seen with in vivo treatment (18), supporting a direct cellular mechanism of reserpine action.

Although chronic reserpine treatment alters food consumption and growth in rats and mice, the effects of these alterations on the exocrine pancreas have not been considered $(19,20)$. Decreased food consumption (malnutrition) or fasting in the rat also can result in decreased pancreatic amylase content $(21,25)$. Consequently, this study was undertaken to determine the effects of malnutrition and chronic reserpine treatment on the rat exocrine pancreas using pair fed-sham controls.

\section{MATERIALS AND METHODS}

Male, Sprague-Dawley rats (100-180 g) were housed individually in hanging cages at $25^{\circ} \mathrm{C}$ with a $12 \mathrm{~h}$ light/dark cycle. Rats were fed Wayne rodent food (Wayne Pet Food Div., Continental Grain Co., Chicago, IL) as indicated below and water ad libitum. Rats were weight-matched into four groups: C, CS, PFS, and 
CRT and were injected subcutaneously daily for 5 to 7 days as follows: 1) no injection (C); 2) $1.0 \mathrm{ml} / \mathrm{kg} 2 \%$ propylene glycol$8 \%$ ethanol-5\% glacial acetic acid (CS and PFS); or 3) $0.5 \mathrm{mg} /$ $\mathrm{kg}$ reserpine (CRT). Reserpine (Sigma Chemical Co., St. Louis, MO) was dissolved in $0.05 \mathrm{ml}$ glacial acetic acid and diluted with $2 \%$ propylene glycol and $8 \%$ ethanol. The $\mathrm{pH}$ was adjusted to 4.5 with $1 \mathrm{~N} \mathrm{NaOH}$. C, CS, and CRT rats were fed ad libitum. PFS rats were fed at $1630 \mathrm{~h}$ daily the amount of chow consumed in the previous $24 \mathrm{~h}$ by the CRT rats. Food consumption and body weights were determined daily.

To measure pancreatic enzyme content, rats were killed on day 8 between 0900 and $1030 \mathrm{~h}$. The pancreata were removed and frozen at $-80^{\circ} \mathrm{C}$. Pancreata were homogenized in phosphatebuffered saline- $1 \%$ trypsin inhibitor and centrifuged at $16,000 \times$ $g, 4^{\circ} \mathrm{C}, 30 \mathrm{~min}$. The supernatant was analyzed for amylase (E.C. 3.2.1.1) by the Phadebas method using the Phadebas standard reference serum (26), for protein by the Lowry method using bovine serum albumin as the standard (27), for DNA by a microfluorometric method (28), and for lipase (E.C. 3.1.1.3) by a titrimetric method (29).

To determine pancreatic secretion, rats were killed on day 6 following an overnight fast. Fasting overnight reduced variability of secretion among rats; however, rats treated for 7 days with reserpine had a limited tolerance for fasting. Therefore, rats were killed after 5 days of reserpine-treatment rather than 7 days to ensure viability of the isolated acini. Isolated pancreatic acini were prepared as previously described $(30,31)$. Following injection of pancreatic tissue with $10 \mathrm{ml} \mathrm{KHB}$ containing 300-350 U collagenase (Cooper Biomedical, Malvern, PA) and $18 \mathrm{mg}$ hyaluronidase (Sigma Chemical, St. Louis, MO), acini were separated from cellular debris by sedimentation in KHB buffer containing $4 \%$ bovine serum albumin (30). Acini were then preincubated in HEPES-buffered Ringer's solution supplemented with $0.01 \%$ soybean trypsin inhibitor (HR buffer) for 60 min at $37^{\circ} \mathrm{C}(30)$. Viability was monitored by trypan blue exclusion and was always greater than $95 \%$.

Before use in secretion experiments, acini were resuspended in 40 to $50 \mathrm{ml}$ fresh HR buffer. Amylase activity in the supernatant and cell pellets was assayed as described to obtain total amylase content. Aliquots of suspensions of acini were then incubated at $37^{\circ} \mathrm{C}$ for $30 \mathrm{~min}$ with or without various concentrations of $\mathrm{CCK}_{8}$ (30). Amylase release during this incubation was expressed as the percent of acinar amylase released in the presence of $\mathrm{CCK}_{8}$ compared to the release in the absence of $\mathrm{CCK}_{8}$ (control).

Data were analyzed by ANOVA and LSD (32). Differences were significant when $p<0.05$. Data are expressed as mean \pm SEM.

\section{RESULTS}

After 2 days, the CRT rats became hypodynamic and exhibited palpebral ptosis and diarrhea, while $C$ and PFS rats exhibited normal behavior. CRT and PFS rats consumed significantly ( $p$ $<0.001$ ) less food $(40 \%)$ than the $C$ group (Table 1$)$. Pancreatic weights significantly decreased $(p<0.001)$ in the reserpinetreated $(65 \%)$ and PFS $(62 \%)$ rats (Table 1$)$. The ratio of pancreatic weight to body weight significantly increased $(p<0.001)$ only in the reserpine-treated rats. C and CS rats gained $44 \%$ of initial body weight in 8 days while the CRT and PFS rats lost 26 and $20 \%$ of initial weight (Fig. 1). C and CS rats had significantly $(p<0.001)$ greater final weights than PFS $(59 \%)$ and reserpinetreated $(51 \%)$ rats. Further, the final body weight of PFS rats was significantly greater than that of reserpine-treated rats.

Total pancreatic amylase-activity (U) decreased significantly $(p<0.05)$ in the reserpine-treated $(49 \%)$ and PFS $(56 \%)$ rats compared to the $\mathrm{C}$ group (Fig. 2). However, total amylase-activity was comparable in the reserpine-treated and PFS rats. Specific amylase activity (U/mg pancreatic protein) also significantly
Table 1. Effects of reserpine treatment on food consumption and pancreas*

\begin{tabular}{lccc}
\hline & $\begin{array}{c}\text { Food } \\
\text { consumption } \\
\text { Treatment }\end{array}$ & $\begin{array}{c}\text { Pancreas wt } \\
(\mathrm{g})\end{array}$ & $\begin{array}{c}\text { Ratio of } \\
\text { pancreatic wt }(\mathrm{g}) \\
\text { to body wt }(\mathrm{g}) \\
\left(\times 10^{-3}\right)\end{array}$ \\
\hline $\mathrm{C}$ & $21.7 \pm 0.6^{a}$ & $0.92 \pm 0.02^{a}$ & $5.21 \pm 0.099^{b c}$ \\
$\mathrm{CS}$ & $21.5 \pm 0.5^{a}$ & $0.83 \pm 0.02^{b}$ & $4.80 \pm 0.142^{c}$ \\
PFS & $8.8 \pm 0.4^{b}$ & $0.60 \pm 0.02^{c}$ & $5.71 \pm 0.113^{b}$ \\
Reserpine & $8.8 \pm 1.0^{b}$ & $0.57 \pm 0.04^{c}$ & $6.37 \pm 0.363^{a}$ \\
\hline
\end{tabular}

$*$ Values are mean \pm SEM of 8 rats. Rats were fed rat food, weightmatched into groups and injected daily subcutaneously with 1) no injection and fed ad libitum (C), 2) $1.0 \mathrm{ml} / \mathrm{kg} 2 \%$ propylene glycol- $8 \%$ ethanol-5\% acetic acid and fed ad libitum (CS), 3) $0.5 \mathrm{mg} / \mathrm{kg}$ reserpine and fed ad libitum (reserpine), and 4) $1.0 \mathrm{ml} / \mathrm{kg}$ sham and fed the amount of food consumed by the reserpine-treated group (PFS). After 7 days, rats were killed and pancreata removed.

ahc Values for a given parameter not sharing a superscript are significantly different $(p<0.001)$ by ANOVA and LSD.

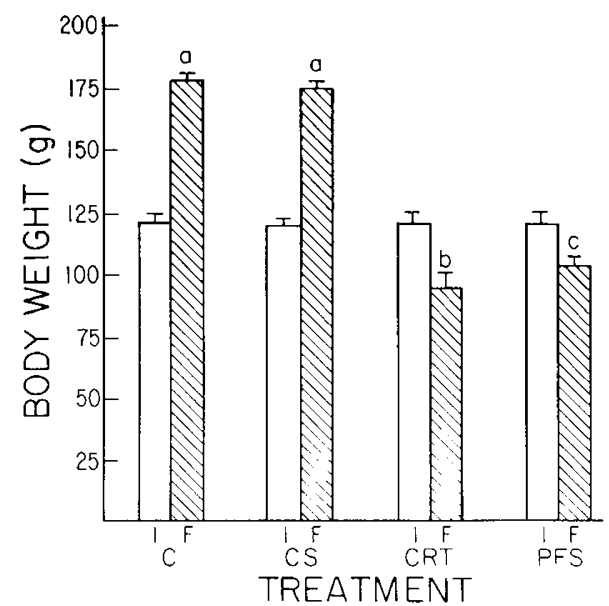

Fig. 1. Effects of chronic reserpine treatment on growth of rats. Rats were fed rat food, weight-matched into groups, and treated daily subcutaneously with injections as follows: 1) $C$, no injection and fed ad libitum, 2) $C S, 1.0 \mathrm{ml} / \mathrm{kg} 2 \%$ propylene glycol- $8 \%$ ethanol-5\% glacial acetic acid and fed ad libitum, 3) CRT, $0.5 \mathrm{mg} / \mathrm{kg}$ reserpine and fed ad libitum, and 4) PFS, $1.0 \mathrm{ml} / \mathrm{kg}$ sham and fed the amount of food consumed by the reserpine-treated group. Initial $(I)$ and final $(F)$ body weights are shown as mean \pm SEM for eight rats. ${ }^{\text {atc }}$ Values are significantly different than corresponding control values $(P<0.05)$ by ANOVA and LSD.

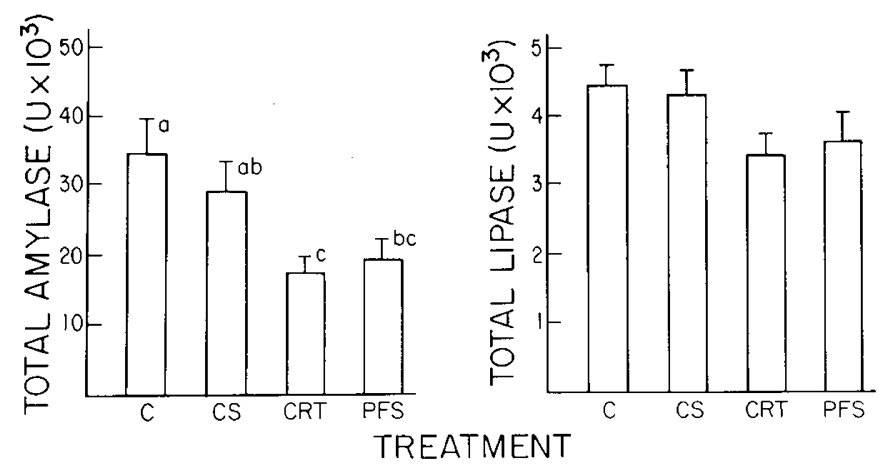

Fig. 2. Effects of chronic reserpine treatment on pancreatic enzymes. Rats were fed rat food, weight-matched into groups, and treated with daily injections subcutaneously as described in Figure 1. Values are mean \pm SEM of eight rats. ${ }^{a b c}$ Values for a given parameter not sharing a superscript are significantly different $(P<0.05)$ by ANOVA and LSD. 
Table 2. Effects of reserpine treatment on pancreatic exocrine function*

\begin{tabular}{lccc}
\hline Treatment & $\begin{array}{c}\text { DNA } \\
(\mu \mathrm{g})\end{array}$ & $\begin{array}{c}\text { Pancreatic } \\
\text { protein } \\
(\mathrm{mg})\end{array}$ & $\begin{array}{c}\text { Amylase } \\
(\mathrm{U} / \mathrm{mg} \text { protein })\end{array}$ \\
\hline $\mathrm{C}$ & $64 \pm 7^{a}$ & $108 \pm 5^{a}$ & $341 \pm 44^{a}$ \\
$\mathrm{CS}$ & $51 \pm 2^{a}$ & $101 \pm 4^{a b}$ & $293 \pm 44^{a b}$ \\
PFS & $48 \pm 5^{a}$ & $92 \pm 7^{b c}$ & $208 \pm 18^{b}$ \\
Reserpine & $59 \pm 10^{a}$ & $81 \pm 5^{c}$ & $210 \pm 21^{b}$ \\
\hline
\end{tabular}

$*$ Values are mean \pm SEM of 8 rats. Rats were fed rat food, weightmatched into groups and injected daily subcutaneously as described in Table 1.

ahc Values for a given parameter not sharing a superscript are significantly different $(p<0.05)$ by ANOVA and LSD.

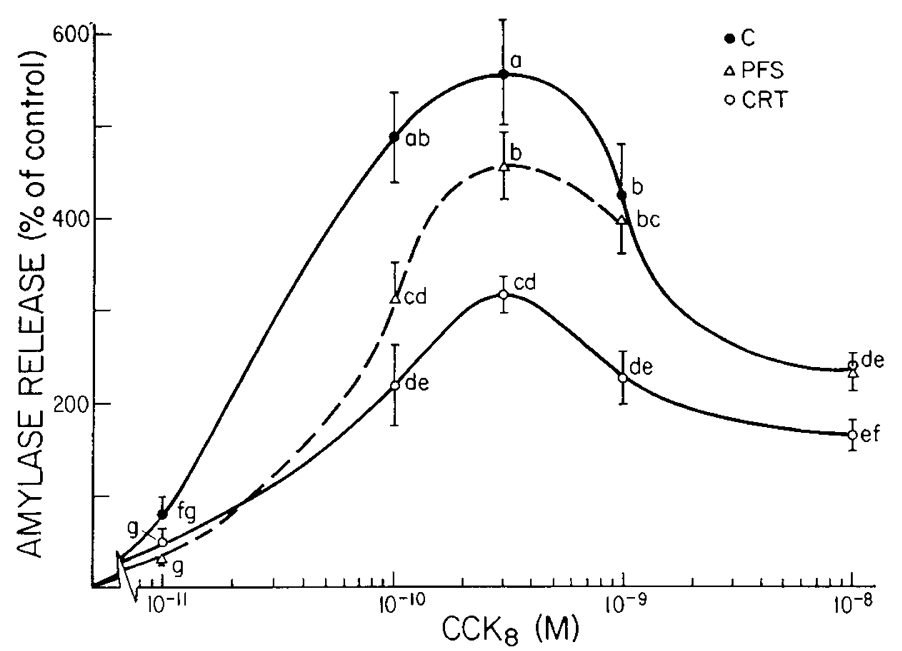

Fig. 3. Effect of $\mathrm{CCK}_{8}$ on amylase release. Acini were incubated for $30 \mathrm{~min}$ with or without the indicated concentrations of $\mathrm{CCK}_{8}$. Values are expressed as the percent of acinar amylase released in the presence of $\mathrm{CCK}_{8}$ compared to the respective release in the absence of $\mathrm{CCK}_{8}(\mathrm{C})$ and are mean \pm SEM of four or five experiments. ${ }^{\text {abcdefg }}$ Values not sharing a superscript differed significantly $(P<0.05)$ by 2 -way ANOVA and LSD.

decreased $(p<0.005)$ in the reserpine-treated $(62 \%)$ and PFS $(61 \%)$ rats compared to the $C$ group, but again was comparable between reserpine-treated and PFS rats (Table 2). Pancreatic protein also decreased comparably in the reserpine-treated $(75 \%)$ and PFS $(85 \%)$ rats. Pancreatic lipase was not altered by reserpine treatment or food restriction compared to $\mathrm{C}$ rats (Fig. 2). DNA also was comparable among the four groups (Table 2).

$\mathrm{CCK}_{8}$ exerted a characteristic dose-dependent effect on amylase release in acini prepared from $\mathrm{C}, \mathrm{PFS}$, and reserpine-treated rats (Fig. 3). Maximal stimulation of amylase release occurred at $3 \times 10^{-10} \mathrm{M} \mathrm{CCK}_{8}$ in all three groups. Higher concentrations of $\mathrm{CCK}_{8}$ were less effective, exhibiting what has been termed a restricted stimulation. The magnitude of the stimulatory effect was greatest in the controls, intermediate in the PFS, and least in the reserpine-treated group. Further, there was a highly significant $\left(p<0.0001, \mathrm{~F}_{2.67}=28.629\right)$ effect of in vivo reserpine treatment on the secretory responsiveness of isolated acini as analyzed by 2-way ANOVA and LSD.

\section{DISCUSSION}

Reserpine-treatment of rats resulted in decreased food consumption as previously reported in neonatal rats (20) and adult mice (19). The decreased food consumption resulted in lower body weights $(19,20)$. In the present study, the decreased body weight cannot be attributed solely to decreased food consumption because the PFS rats lost less weight than the reserpinetreated rats despite comparable food intake. The $40 \%$ decrease in food consumption, $49 \%$ decrease in body weight, and the $39 \%$ decrease in pancreatic weight in reserpine-treated rats demonstrated that reserpine treatment induced malnutrition.

Pancreata were smaller in the reserpine-treated and PFS rats compared to $\mathrm{C}$ rats. However, pancreatic weight was greater relative to total body weight in the reserpine-treated rats. In contrast, Perlmuter and Martinez show a significant reduction in pancreas weight of reserpine-treated rats, but the ratio of pancreatic weight to body weight remains comparable to the $\mathrm{C}$ rats (15). Chung et al. (20), however, report slightly higher pancreatic weights relative to body weight in reserpine-treated rat pups compared with controls. The higher pancreatic weight to body weight ratios suggest a relative sparing of the pancreas in reserpine-treatment.

Our results showed that chronic reserpine-treatment decreased rat pancreatic protein, amylase, and specific amylase activity. Similarly, Joehl and DeJoseph (16) show a significant decrease in the total amylase content of rat pancreatic acini isolated from CRT rats. However, these parameters were comparably decreased in the malnourished PFS rats in the present study. Other studies of malnutrition show either a parallel decrease in pancreatic enzymes (20) or a nonparallel decrease in pancreatic amylase and an increase in pancreatic lipase $(23,24)$. Pancreatic lipase, however, was not affected by either reserpine-treatment or malnutrition (PFS) in this study resulting in a nonparallel change in pancreatic enzymes. The decreased amylase and total protein observed in both the reserpine-treated and PFS rats suggest that the reserpine-induced alterations in pancreatic enzyme content may be secondary to the malnutrition.

Despite the comparable decrease in amylase content in pancreata from PFS and CRT rats, the secretory response of these acini were distinctly different. $\mathrm{CCK}_{8}$-mediated amylase-release in acini prepared from PFS rats was significantly greater than the release by CRT acini and significantly less than C acini (Fig. 3 ). Although chronic reserpine treatment caused a markedly attenuated secretory response over a wide concentration range of $\mathrm{CCK}_{8}$, it did not shift the dose-response curve. This attenuated responsiveness might be due either to a receptor or postreceptor defect. Irrespective of the underlying mechanisms, these data indicate that the alterations in secretory responsiveness resulting from malnutrition only partly account for those induced by reserpine.

Results from the present study suggest that chronic reserpine leads to a dual defect in the exocrine pancreas. One defect can be attributed to the malnutrition induced by reserpine treatment, while the other is more directly related to the reserpine treatment. Therefore, studies using the reserpine-treated experimental model need to control for the induced malnutrition by using appropriate pair feeding.

\section{REFERENCES}

1. Martinez JR, Adelstein E, Quissell D, Barbero GJ 1975 The chronically reserpinized rat as a possible model for cystic fibrosis. I. Submaxillary gland morphology and ultrastructure. Pediatr Res 9:463-469

2. Martinez JR, Adheads PC, Quissell D, Barbero GJ 1975 The chronically reserpinized rat as a possible model for cystic fibrosis. II. Composition and cilioinhibitory effects of submaxillary saliva. Pediatr Res 9:470-475

3. Setser ME, Spicer SS, Simpson JAV, Martinez JR 1979 Altered granule discharge and amylase secretion of parotid glands in reserpine-treated rats. Lab Invest 41:256-264

4. Simpson JAV, Spicer SS, Setser ME, Martinez JR 1978 Histochemistry and ultrastructure of rat submandibular acinar cells. Effects of chronic reserpine on secretion. Lab Invest 39:157-166

5. Mawhinney TP, Feather MS, Martinez JR, Barbero GJ 1979 The chronically reserpinized rat as an animal model for cystic fibrosis: acute effect of isoproterenol and pilocarpine upon pulmonary lavage fluid. Pediatr Res 13:760-763

6. Mawhinney TP, Martinez JR, Feather MS, Barbero GJ 1980 Effect of kinin, peptides and prostaglandins on glycoprotein release by the perfused trachea of control and reserpine treated rats. Cystic Fibrosis Club Abstracts, San 
Antonio, TX, p 79

7. Morton D. Parker D. Estrada P. Martinez JR 1980 Exocrine pancreatic secretion in rats treated with reserpine after stimulation with pilocarpine, dopamine, caerulein. Pediatr Res 14:18-20

8. Brady RC. Karnaky KJ, Dedman JR 1985 Colonic glycoprotein secretion and calmodulin-acceptor proteins in the reserpine-treated rat. Am $J$ Physio 248:G54-G60

9. Forstner J. Maxwell B, Roomi N 1981 Intestinal secretion of mucin in chronically reserpine-treated rats. Am J Physiol 241:G443-G450

10. Quissell DO. Martinez JR, Giles M 1979 Electrolyte and energy changes following parasympathomemetic and sympathomemetic stimulation in submandibular salivary glands of rats treated with reserpine. Arch Oral Biol 24:639-644

11. Wood DL, Martinez JR 1977 The chronically reserpinized rat as a possible model for cystic fibrosis. VI Synergistic effects of isoproterenol and $\mathrm{Ca}^{2+}$ and protein in the submaximally gland. Pediatr Res 11:827-832

12. Setser ME. Spicer SS, Simpson JAV, Adamson M. Martinez JR 1979. The effects of reserpine on the ultrastructure and secretory responses of rat exocrine pancreas. Exp Mol Pathol 31:413-422

13. McCurdy RE. Martinez JR 1981 The chronically reserpinized rat as a model for cystic fibrosis: alterations in pancreatic enzyme secretion and storage. Pediatr Res 15:1308-1313

14. Roomans GM. Wei X. Ceder O. Kollberg H 1982 The reserpinized rat in the study of cystic fibrosis: $x$-ray microanalysis of submandibular gland and pancreas. Ultrastruct Pathol 3:285-293

15. Perlmutter J. Martinez JR 1978 The chronically reserpinized rat as a possible model for cystic fibrosis. VII. Alterations in the secretory response to cholecystokinin and to secretin from the pancreas in vivo. Pediatr Res 12:188194

16. Joehl RJ, DeJoseph MR 1985 Pancreatic enzyme secretion in experimental cystic fibrosis. In: Martinez JR, Barbero GJ (eds) Animal Models For Cystic Fibrosis: The Reserpine-Treated Rat. San Francisco Press, Inc., San Francisco, pp 119-124

17. Kanner BI. Fishkes H. Maron R. Sharon I. Schuldiner S 1979 Reserpine as a competitive and reversible inhibitor of the catecholamine transporter of bovine chromaffin granules. FEBS Lett 100:175-177

18. Brady RC. Karnaky J. Dedman JR 1984 Reserpine-induced alterations in mucus-production and calmodulin-binding proteins in a human epithelial cell line. Exp Cell Res 150:141-151

19. Sordelli DO, Cassino RJJ, Pivetta OH 1979 Animal model for cystic fibrosis: pulmonary clearance of Staphylococcus aureus in mice treated with reserpine. Life Sci 24:2003-2010

20. Chung KS, Lee PC, Brooks S, Lebenthal E 1984 Effect of chronic reserpine treatment on the pancreases of neonatal rats. Pediatr Res 18:1300-1304

21. Fujino M 1957 Enzymological studies on experimental malnutrition. Tokushima J Exp Med 4:8-23

22. Veghelyi PV, Kemeny TT 1961 Protein metabolism and pancreatic function. In: Reuck AVS, Cameron MP (eds) Ciba Foundation Symposium on the Exocrine Pancreas. Boston, MA, Little Brown, pp 329-349

23. Webster PD, Singh M, Tucker PC, Black O 1972 Effects of fasting and feeding on the pancreas. Gastroenterology 62:600-625

24. Christophe J, Camus J, Deschodt-Lanckman J, Rathe J, Robberecht P, Vandermeers-Peret MG, Vandermeers A 1971 Factors regulating biosynthesis, intracellular transport and secretion of amylase and lipase in the rat exocrine pancreas. Horm Metab Res 3:393-403

25. Lee PC, Brooks S, Lebenthal E 1982 Effect of fasting and refeeding on pancreatic enzymes and secretagogue responsiveness in rats. Am J Physiol 242:G215-G221

26. Ceska M, Birath K, Brown B 1969 A new and rapid method for the clinical determination of a-amylase activities in human serum and urine. Clin Chim Acta 26:437-439

27. Lowry OH, Rosebrough NJ, Far AL, Randall RJ 1957 Protein measurement with the folin phenol reagent. J Biol Chem 193:265-275

28. Cattolico RA, Gibbs SP 1975 Rapid filter method for the Microfluorometric analysis of DNA. Anal Biochem 69:672-682

29. Naher G 1974 Lipase titrimetric assay. In: Bergmeyer HU (ed) Methods of Enzymatic Analysis, vol 2. Academic Press, New York, pp 814-818

30. Korc M 1982 Regulation of pancreatic protein synthesis by cholecystokinin and calcium. Am J Physiol 243:G69-G75

31. Williams JA, Korc M, Dormer RL 1978 Action of secretagogues on a new preparation of functionally intact isolated pancreatic acini. Am J Physiol 235:E517-E524

32. Steel RGO, Torie JH 1960 Principles and Procedures of Statistics. McGrawHill Book Co., Inc., New York 